\author{
Gabriela HANUS, PhD \\ College of Management, University of Economics in Katowice \\ e-mail: gabriela.hanus@uekat.pl \\ ORCID: 0000-0002-1028-0670
}

DOI: $10.15290 /$ oes.2021.02.104.02

\title{
THE PHENOMENA OF GLOBALISATION IN POLISH CONSUMERS' FOOD CHOICES ${ }^{1}$
}

\begin{abstract}
Summary
Purpose - To identify and characterise the phenomena of globalisation in the food choices of Polish consumers. To identify demographic, economic and social determinants influencing the level of globalization in the dietary choices of Poles, as well as to recognise the most important factors determining consumers' dietary choices.

Research method - Direct surveys among 660 respondents using quantitative methods were used. The collected data was analysed using the factor analysis (the main component method), Cronbach's alphafactor, structured logit models, Pearson's $\chi^{2}$ and Cramer's V coefficients, as well as descriptive statistics and structure indicators.

Results - The phenomenon of globalisation is clearly visible in the nutritional choices of Poles. Its impact is manifested primarily in the purchase of fast food in fast food bars and food products in international trade chains; however, it should be noted that this phenomenon concerns primarily the younger generation (under 25), with higher education, and people assessing their income situation as very good.

Implications / recommendations - Because of the fashion for healthy, plant-based nutrition, it can be assumed that today's consumers are looking for a dietary alternative that will allow them to reduce the time it takes to prepare meals and clean up afterwards, while maintaining their health. There may be a growing demand for fast food bars offering healthy food from a proven source. Moreover, due to the increasingly prevalent demands of antiglobalists and the coronavirus crisis, the phenomena of ethnocentrism and deconsumption in consumer behaviour increasingly emerge as trends alternative to globalisation and, as such, they merit further investigation.
\end{abstract}

Keywords: consumers' food choices in Poland, globalisation, new trends

JEL Classification: D12, E20

\section{Introduction}

There is no doubt that globalisation is the main drive behind any market transformation. It is thanks to globalisation that new trends in consumer behaviour, first visible on Western markets, gradually spread all over the world, creating lifestyles,

1 Article received on 17 September 2020, accepted on 9 March 2021. 
demand for selected products and services and ways of shopping. Consumer behaviour is indeed determined by the marketing strategies of companies that seek to meet the needs of their customers best. Therefore, it seems extremely important to examine whether and to what extent Polish consumers exhibit the influences of globalisation in their food choices.

The main purpose of this paper is to identify and characterise the phenomenon of globalisation in the food choices of Polish consumers. The realization of the cognitive objective formulated in this way required: identifying demographic, economic and social determinants influencing the level of globalization in the dietary choices of Poles, as well as recognizing the most important factors determining consumers' dietary choices.

Four hypotheses are drawn up: 1) The phenomenon of globalisation is visible in Polish consumers' food choices; 2) Consumers with higher education have a greater interest in convenience and fast food and are more likely to buy food products from international retail chains; 3) Easier availability of international restaurants and retail chains is believed to influence consumer choices; 4) Consumer lifestyles are presumed to influence fast food purchases.

The subjective scope of the primary research concerns individual consumers who independently decide about their diet (over 18 years of age). Direct research was conducted in the third quarter of 2018 and covered the entire territory of Poland.

It should be noted that there are some restrictions in this research, which should be indicated. First of all, the studies carried out are non-exhaustive. As such, it is not possible to draw general conclusions for the whole population. Secondly, the research method is a questionnaire, which is not without flaws, such as superficiality and limited scope for engaging in depth in the subject.

The paper is divided into the following sections: the first presents the phenomenon of globalisation in theory; the second is dedicated to methodology and data collection, while the third presents the empirical results and discussion. The conclusion provides a summary and indicates possible applications and further research directions.

\section{Globalisation in literature}

The phenomenon of globalisation is defined as a spontaneous and historical process, which involves the integration of capital, labour force, markets information and technology into one interdependent global market [Lemańska-Majdzik, Sobiegraj, 2013, p.115; Hanus, 2018, p. 170]. Some authors find that globalisation is a process by which regional cultures, societies and economies are integrated through a global network of exchange of people, ideas, material goods and information [Robbins et al., 2010, p. 55; Maśloch, 2013, p. 148; Hanus, 2018, p. 170]. Therefore, the five types of global flows can be indicated: flows of know-how and technology, flows of tourists or migrants, flows of capital and money, flows of political ideologies, and flows of communication [Gupta, 2011, p. 253; Hanus, 2018, p. 170]. 
Michałowska and Danielak [2015] notice that mass culture is a dynamic, revolutionary force that eradicates class divisions, tradition, taste and blurs cultural distinctions', which means that it has significant impact on the development of consumer behaviour, their lifestyle and preferences. Globalisation and the changes that accompany it are manifested in the sphere of consumption primarily by creating new forms of consumption and consumer behaviour, opening new sales locations, and creating new products and new consumer needs [Włodarczyk, 2015, p. 66].

The globalisation of consumption is manifested by the interpenetration of consumption patterns between cultures. This phenomenon means that ordinary people are not always aware of the changes taking place around them, noting only borderless trade and easy access to goods and services. In the long run, despite the lack of awareness of the changes, consumers adopt increasingly similar purchasing habits, preferences and attitudes, succumbing to the fashions for global products. The phenomenon is fuelled by transnational corporations that exploit the ignorance of buyers and shape their needs through various means of influence, such as TV, radio and press advertising, product placement and merchandising. In the literature on the subject, there are three areas focusing on the globalisation of consumption. The first is the market environment and conditions that are conducive to meeting consumer needs, such as commercial and service infrastructure, the expansion of hypermarkets, as well as legal regulations for the protection of consumer interests. The second area consists of popular shopping habits, brands and offers for particular market segments. The third area is the hierarchy of needs, resulting from values, norms and implemented lifestyles formed by the development of Western civilization [Włodarczyk, 2015, p. 66-67].

In the field of consumer food choices, globalisation is considered as one of the most important factors shaping consumer' food choices [e.g. Hughes, Lawerence, 2005; Schultz, 2004; Ukonu, 2007; Hanus, 2018]. This is mainly due to the easy access to the product, the media, Internet development, fast-food restaurants (KFC, McDonald's, Pizza Hut), facilitated mobility, food fashion and dietary recommendations. Buying global products, expressing modern and desired lifestyles, contributes to the similarity of consumption patterns and consumer behaviour, thus leading to an increased role of some previously unimportant determinants of consumption. Psychosocial regularities have become particularly important in the formation of household consumption, determining the willingness to buy and manifesting themselves in such areas as social and intra- and intergroup imitation, international imitation, ostentatious consumption, the show effect and fashion. It is worth noting that fashion, on one hand, makes it possible to express one's individuality and, on the other hand, is evidence of belonging to a particular group [Niemczyk, 2004, p. 166].

There are a lot of examples of international researches focusing on this subject. The researches focus primarily on the relationship between food globalization and population's health, dietary changes, food security and consumer preferences for fast food, convenience food, and functional food [e.g. Hughes, Lawerence, 2005; Schultz, 2004; Ukonu, 2007; McLean-Meyinsse et al., 2015; Brunner et al., 2010; 
Goetzke at al., 2014]. For example, Hughes and Lawrence [2005] note that globalisation is considered as a critical aspect of the nutritional transformation in the Pacific affecting the health and wellbeing of populations. Also Schultz [2004] indicates that globalisation has negative social, health and nutritional effects in Fiji. On the other hand, Ukonu [2007] investigates the impact of globalization on the nutritional behaviour of students at the University of Central Lancashire, United Kingdom and proves that globalization strengthened the evolution of fast food, popularizing it among students.

As it can be noticed, globalization of food has a direct impact on human health and life, causing many controversial discussions. Therefore, it seems justified to study its manifestations in the nutritional choices of the population, including Poles.

\section{Data and Methodology}

In order to achieve the objectives of this article and to verify the hypotheses adopted, it was necessary to conduct primary and secondary research of a quantitative nature. Secondary research concerned the theoretical background of the phenomenon of globalisation, while primary research focused only on the identification of this phenomenon ${ }^{2}$ in the Polish consumers' food choices and the factors shaping it. Individual consumers independently deciding on their diet (over 18 years of age) took part in the direct research using quantitative methods. The research was conducted in 2018 across Poland. The measurement tool in the primary research was a questionnaire, which consisted of an introduction, instructions for respondents, ten relevant questions and five questions about demographic items.

The primary source of the survey included the results of an online and a distributed survey covering the whole of Poland. A total of 660 people took part in the study, including 393 women (59.5\%) and 267 men (40.5\%). People aged 18-34 constituted about $42 \%$ of those surveyed, people aged 35-54 formed $28 \%$, and people aged over 55 were $31 \%$ of those surveyed. The structure of the sample in terms of age and gender resulted from the quota selection, which reflected the structure of the population in Poland as of 31.12.2016. Other characteristics of the research sample included: education, income situation and place of residence. Almost half of the respondents had secondary education (49.5\%), over $1 / 3$ had vocational education $(35.3 \%)$, and every seventh person had higher education. Only $2.3 \%$ of respondents declared primary or lower secondary education (table 1).

In order to examine the degree of occurrence of globalisation as a new trend in Poles' eating behaviour, variables were operationalised. Table 2 presents how globalisation was measured. The manifestations of globalization in the dietary choices of Polish consumers were examined using three questions. The first and

\footnotetext{
2 It should be noted that, apart fromglobalisation, research was intended to identify other trends in the food choices of Polish consumers; however, this paper focuses only on globalisation in order to realise its objectives and hypotheses.
} 
second were related to the frequency of consuming fast food, e.g. french fries, hamburgers, pizza, hot dogs or casseroles, and doing food shopping in international retail chains such as Auchan, Tesco, Carrefour supermarkets Whereas the third question asked about the degree of interest in new trends in nutrition, introducing trendy products into daily diet and looking for new ways of cooking.

TABLE 1

Characteristics of consumers participating in the survey $(n=660)$

\begin{tabular}{|c|c|c|}
\hline \multirow{2}{*}{ Characteristics of respondents } & \multicolumn{2}{|c|}{ Respondents } \\
\hline & Number & $\%$ \\
\hline \multicolumn{3}{|l|}{ Gender } \\
\hline Female & 393 & $59.50 \%$ \\
\hline Male & 267 & $40.50 \%$ \\
\hline \multicolumn{3}{|l|}{ Age } \\
\hline $18-24$ & 103 & $15.6 \%$ \\
\hline $25-34$ & 166 & $25.2 \%$ \\
\hline $35-44$ & 102 & $15.5 \%$ \\
\hline $45-54$ & 84 & $12.7 \%$ \\
\hline $55-59$ & 50 & $7.6 \%$ \\
\hline $60-64$ & 50 & $7.6 \%$ \\
\hline 65 years and above & 105 & $15.9 \%$ \\
\hline \multicolumn{3}{|l|}{ Education } \\
\hline Basic & 6 & $0.9 \%$ \\
\hline Junior High School & 9 & $1.4 \%$ \\
\hline Professional & 233 & $35.3 \%$ \\
\hline Average & 327 & $49.5 \%$ \\
\hline Higher & 85 & $12.9 \%$ \\
\hline \multicolumn{3}{|l|}{ Income situation } \\
\hline Very bad & 13 & $2.0 \%$ \\
\hline Bad & 8 & $1.2 \%$ \\
\hline Average & 104 & $15.8 \%$ \\
\hline Okay & 235 & $35.6 \%$ \\
\hline Very good & 300 & $45.5 \%$ \\
\hline \multicolumn{3}{|l|}{ Place of residence } \\
\hline City & 407 & $61.7 \%$ \\
\hline Village & 253 & $38.3 \%$ \\
\hline
\end{tabular}

Source: own elaboration based on primary research results. 
TABLE 2

Operationalisation and measurement of variables

\begin{tabular}{|c|c|c|}
\hline $\begin{array}{c}\text { Studied } \\
\text { phenomenon }\end{array}$ & Scale position (questions) $*$ & $\begin{array}{c}\text { Alpha Cronbach } \\
\text { for the scale }\end{array}$ \\
\hline \multirow{3}{*}{ Globalisation } & $\begin{array}{c}\text { Acquisition of fast food products, e.g. french fries, } \\
\text { hamburgers, pizza, hot dogs, casseroles }\end{array}$ & \multirow{2}{*}{ Alpha $=0.040^{* * *}$} \\
\cline { 2 - 2 } & Purchasing food in international retail chains & \\
\cline { 2 - 3 } & Taking an interest in new trends in nutrition & \\
\hline
\end{tabular}

* Intensity scales from 1 to 5 were used in the questions; the ends of these scales were described differently depending on the question asked ** Result confirming high reliability of measurement; measuring dependent variables on summary scales $* * *$ Not reliable; analysis of answers to individual questions.

Source: own study.

For data analysis, a factor analysis and Cronbach's alpha-factor, structured logit models, Pearson's $\chi^{2}$ and Cramer's V coefficients were used. Moreover, some descriptive statistics and structure indicators for single questions were also determined.

\section{Results and Discussion}

In order to determine the importance of selected factors on Polish consumers' food products choices, respondents were asked to rate, on a scale of 1-5, the importance of the given factors when choosing a food product. As shown in chart 1, composition was found to be important or very important to almost $45 \%$ of consumers, only $1.2 \%$ said it was not important to them. Almost $3 / 4$ of Poles pay attention to the calorific value of products, but $4.3 \%$ do not attach any importance to it at all. Almost $80 \%$ of respondents believe that quality is important or very important to them when choosing food products, while about $45 \%$ of consumers pay attention to the company. Over $50 \%$ of respondents admit that the price of products plays at least an important role in their choice. The packaging of products proved to be the least important for consumers: $15.6 \%$ of consumers answered 'not important' (table 3).

TABLE 3

The importance of selected factors when choosing a food product among Poles

\begin{tabular}{|l|c|c|c|c|c|c|}
\hline & Packaging & Price & Company & Quality & Calories & Composition \\
\hline Not important & $15,6 \%$ & $6,6 \%$ & $8,6 \%$ & $4,4 \%$ & $4,3 \%$ & $1,2 \%$ \\
\hline Rather not important & $32,4 \%$ & $16,8 \%$ & $16,1 \%$ & $7,4 \%$ & $5,2 \%$ & $2,2 \%$ \\
\hline Hard to say & $16,8 \%$ & $23,9 \%$ & $28,9 \%$ & $9,4 \%$ & $15,8 \%$ & $6,2 \%$ \\
\hline Important & $31,8 \%$ & $44,6 \%$ & $32,2 \%$ & $61,4 \%$ & $39,3 \%$ & $44,3 \%$ \\
\hline Very important & $3,3 \%$ & $8,1 \%$ & $14,2 \%$ & $17,4 \%$ & $35,4 \%$ & $46,2 \%$ \\
\hline
\end{tabular}

Source: own elaboration based on primary research results. 
As shown by the analysis of the importance of factors in the dietary choices of Poles, the most important is the quality, which is most often discussed when analysing the impact of food globalization on human health [e.g. Ukonu, 2007]. However, direct research conducted for the purposes of this study shows that the globalisation of consumption is undoubtedly a trend visible in the behaviour of Polish consumers. It is indicated that the average score for behaviours in the field of globalisation is 2.92 , and the median is 3 on a five-grade scale (table 4). Ukonu [2016] indicates that although consumers are aware of the health effects of fast food and the significance of using informational labelling on food to make healthful choices, they prefer fast food to better quality home-cooked food. It means that many factors can influence consumers' eating behaviors, such as habit, price, convenience or taste.

TABLE 4

Descriptive statistics for new trends in the nutritional behaviours of Poles*

\begin{tabular}{|c|c|c|c|}
\hline Phenomenon & Average & Median & Standard deviation \\
\hline Globalisation & 2.92 & 3.00 & 1.18 \\
\hline
\end{tabular}

* In the questions, the intensity scales from 1 to 5 were used, and the ends of these scales were described differently depending on the question asked.

Source: own elaboration based on primary research results.

In order to analyse fully the impact of globalisation on the dietary choices of Poles, the frequency with which Poles eat in restaurants with international menus and fast food bars was examined. It was shown that as many as $49 \%$ of respondents used the services of fast food bars, while restaurants with international cuisine, e.g. Chinese, Italian, Mexican, were used by about $42 \%$ (chart 1 ). The customers of restaurants with international cuisine were less often women and people aged 25 years or above than those aged 18-24. People with secondary or higher than vocational education, who assessed their income situation as very good, and who were also city dwellers and consumers keen to expand their knowledge of proper nutrition, ate there more often. Conversely, people who paid attention to the price of food were much less likely to choose restaurants with international cuisine. Fast food bars, such as McDonald's, KFC or Pizza Hut, were less often preferred by women than men.

What is more, people aged 25 and above ate fast food less frequently than consumers aged 18-24. This difference becomes statistically more significant with the increase of the age of the respondents. Furthermore, respondents with lower secondary education ate less frequently in fast food bars than those with vocational education. Those who assessed the income situation of their household as very bad, good or very good chose fast food bars more often than those who assessed their income situation as average. Fast food bars were much less frequently chosen by people who paid attention to the quality of the food they ate, favoured healthy 
nutrition and followed different types of diets (table 5). The research is consistent with the results of the HoReCa market report of 2018 in Poland [www 1], which stated that among the types of catering establishments used by residents in Poland, pizzerias $(95 \%)$ and fast food bars $(90 \%)$ were most frequently indicated.

Another aspect of the advent of globalisation is the expansion of international retail chains (hyper- and supermarkets and discount stores) and the unification of their offers. This contributes to the similarity of food consumption patterns, which is aimed at an easier and more convenient purchase of products.

TABLE 5

\section{Results of estimation of ordered logit models for questions regarding the phenomenon of globalisation}

\begin{tabular}{|c|c|c|c|c|c|c|c|c|}
\hline \multirow[t]{2}{*}{ Question } & \multicolumn{2}{|c|}{$\begin{array}{l}\text { Purchasing food } \\
\text { in international } \\
\text { commercial chains }\end{array}$} & \multicolumn{2}{|c|}{$\begin{array}{l}\text { Buying convenience } \\
\text { products }\end{array}$} & \multicolumn{2}{|c|}{$\begin{array}{l}\text { Buying functional } \\
\text { products }\end{array}$} & \multicolumn{2}{|c|}{ Buying fast food } \\
\hline & $\mathbf{b}$ & std(b) & $\mathbf{b}$ & std(b) & $\mathbf{b}$ & std(b) & $\mathbf{b}$ & std(b) \\
\hline $\begin{array}{l}\text { According to the "you are } \\
\text { what you eat" principle, do } \\
\text { you pay attention to what } \\
\text { food products you } \\
\text { choose? yes }\end{array}$ & 0.120 & 0.308 & 0.215 & 0.264 & 0.542 & $0.274^{* *}$ & 0.658 & $0.270^{* *}$ \\
\hline $\begin{array}{l}\text { What does packaging mean } \\
\text { for you when choosing } \\
\text { a food product? }\end{array}$ & -0.162 & $0.076^{* *}$ & 0.096 & 0.085 & -0.021 & 0.079 & 0.041 & 0.073 \\
\hline $\begin{array}{l}\text { What does price mean for } \\
\text { you when choosing a food } \\
\text { product? }\end{array}$ & 0.387 & $0.100^{* * *}$ & -0.036 & 0,142 & 0.058 & 0.103 & 0.039 & 0.115 \\
\hline $\begin{array}{l}\text { What is the significance } \\
\text { of the company when } \\
\text { choosing a food product? }\end{array}$ & -0.144 & $0.082^{*}$ & 0.242 & $0.089 * * *$ & 0.02 & 0.084 & 0.155 & $0.084 *$ \\
\hline $\begin{array}{l}\text { What is the importance } \\
\text { of quality for you when } \\
\text { choosing a food product? }\end{array}$ & 0.360 & $0.148^{* *}$ & 0.25 & $0.141 *$ & 0.306 & $0.151^{* *}$ & 0.117 & 0.126 \\
\hline $\begin{array}{l}\text { What is the importance } \\
\text { of caloric content for you } \\
\text { when choosing a food } \\
\text { product? }\end{array}$ & 0.055 & 0.087 & 0.015 & 0.107 & 0.209 & $0.097 * *$ & -0.078 & 0.098 \\
\hline $\begin{array}{l}\text { What is the significance } \\
\text { of composition when } \\
\text { choosing a food product? }\end{array}$ & -0.161 & 0.124 & -0.458 & $0.119 * * *$ & -0.038 & 0.112 & -0.274 & $0.112^{* *}$ \\
\hline $\begin{array}{l}\text { Do you think you are } \\
\text { eating healthily?_yes }\end{array}$ & -0.523 & $0.204^{* *}$ & -0.376 & $0.211 *$ & 0.203 & 0.211 & -1.099 & $0.202^{* * *}$ \\
\hline $\begin{array}{l}\text { Do you use any diet } \\
\text { (e.g. vegetable and fruit)? }\end{array}$ & 0.426 & $0.200^{* *}$ & 0.116 & 0.21 & 0.003 & 0.21 & -0.075 & 0.213 \\
\hline $\begin{array}{l}\text { Do you broaden your } \\
\text { knowledge of proper } \\
\text { nutrition? }\end{array}$ & -0.346 & 0.234 & -0.39 & $0.222^{*}$ & 0.726 & $0.207^{* * *}$ & -0.314 & 0.22 \\
\hline $\begin{array}{l}\text { Do you use dietary } \\
\text { supplements advertised } \\
\text { in the media? }\end{array}$ & 0.387 & 0.247 & 0.004 & 0.24 & -0.063 & 0.197 & -0.473 & $0.263^{*}$ \\
\hline sex_female & -0.049 & 0.182 & -0.029 & 0.178 & 0.195 & 0.179 & -0.185 & 0.171 \\
\hline age_25_34 & -0.305 & 0.251 & -0.13 & 0.246 & -0.016 & 0.257 & -0.667 & $0.253^{* * *}$ \\
\hline age_35_44 & -0.549 & $0.272 * *$ & -0.783 & 0.291 *** & -0.197 & 0.301 & -0.882 & $0.276^{* * *}$ \\
\hline age_45_54 & -0.940 & $0.309 * * *$ & -1.007 & $0.287^{* * *}$ & 0.113 & 0.315 & -1.516 & $0.288^{* * *}$ \\
\hline age_55_59 & -1.174 & $0.333^{* * *}$ & -0.913 & $0.345^{\text {*** }}$ & -0.64 & $0.338^{*}$ & -1.953 & $0.438^{* * *}$ \\
\hline
\end{tabular}




\begin{tabular}{|c|c|c|c|c|c|c|c|c|}
\hline \multirow[t]{2}{*}{ Question } & \multicolumn{2}{|c|}{$\begin{array}{l}\text { Purchasing food } \\
\text { in international } \\
\text { commercial chains }\end{array}$} & \multicolumn{2}{|c|}{$\begin{array}{l}\text { Buying convenience } \\
\text { products }\end{array}$} & \multicolumn{2}{|c|}{$\begin{array}{l}\text { Buying functional } \\
\text { products }\end{array}$} & \multicolumn{2}{|c|}{ Buying fast food } \\
\hline & b & std(b) & b & $\operatorname{std}(b)$ & b & std(b) & b & $\operatorname{std}(b)$ \\
\hline age_60_64 & -0.487 & 0.378 & -1.734 & $0.370^{* * *}$ & -0.618 & $0.367^{*}$ & -2.417 & $0.397^{* * *}$ \\
\hline age_65_and_above & -1.341 & $0.348^{* * *}$ & -1.425 & $0.318^{* * *}$ & -0.723 & $0.303^{* *}$ & -3.095 & $0.363^{* * *}$ \\
\hline primary education & -0.522 & 1.428 & -2.276 & $0.860^{* * *}$ & -0.469 & 0.877 & -0.184 & 0.94 \\
\hline $\begin{array}{l}\text { junior high school } \\
\text { education }\end{array}$ & 0.267 & 1.180 & 0.257 & 0.683 & 0.335 & 0.507 & 1.074 & 0.8 \\
\hline secondary education & 0.451 & $0.273^{*}$ & 0.312 & 0.286 & -0.312 & 0.297 & 0.368 & 0.274 \\
\hline higher education & 0.706 & $0.262^{* * *}$ & 0.506 & $0.304 *$ & -0.346 & 0.296 & 0.515 & $0.295^{*}$ \\
\hline very poor income situation & 1.731 & 1.146 & -0.804 & 0.567 & 1.512 & $0.842^{*}$ & 0.76 & 0.725 \\
\hline bad income situation & -0.072 & 0.928 & 0.716 & 0.942 & -0.335 & 0.775 & -0.707 & 0.737 \\
\hline good income situation & 0.212 & 0.195 & -0.226 & 0.203 & 0.213 & 0.202 & 0.279 & 0.194 \\
\hline very good income situation & 0.410 & 0.286 & -0.249 & 0.307 & 0.377 & 0.283 & 0.509 & $0.295^{*}$ \\
\hline place of residence_city & 0.293 & 0.192 & 0.375 & $0.192^{*}$ & 0.174 & 0.187 & -0.277 & 0.199 \\
\hline _cons & 0.075 & & 0.078 & & 0.064 & & 0.151 & \\
\hline $\mathrm{R}^{2}$ & 637 & & 637 & & 637 & & 637 & \\
\hline
\end{tabular}

TABLE 5 [Continued]

\begin{tabular}{|c|c|c|c|c|c|c|}
\hline \multirow[t]{2}{*}{ Question } & \multicolumn{2}{|c|}{$\begin{array}{l}\text { Eating in restaurants } \\
\text { with international } \\
\text { cuisine }\end{array}$} & \multicolumn{2}{|c|}{$\begin{array}{l}\text { Eating in fast food } \\
\text { bars }\end{array}$} & \multicolumn{2}{|c|}{$\begin{array}{l}\text { Taking an interest in } \\
\text { new trends in nutrition }\end{array}$} \\
\hline & b & std(b) & b & $\operatorname{std}(b)$ & b & $\operatorname{std}(b)$ \\
\hline $\begin{array}{l}\text { According to the "you are what you eat" principle, } \\
\text { do you pay attention to what food products you } \\
\text { choose?_yes }\end{array}$ & -0.325 & 0.339 & -0.132 & 0.298 & 0.663 & $0.273^{* *}$ \\
\hline $\begin{array}{l}\text { What does packaging mean for you when } \\
\text { choosing a food product? }\end{array}$ & 0.021 & 0.099 & 0.048 & 0.087 & 0.301 & $0.077^{* * *}$ \\
\hline $\begin{array}{l}\text { What does price mean for you when choosing a } \\
\text { food product? }\end{array}$ & -0.289 & $0.121^{* *}$ & -0.059 & 0.119 & 0.013 & 0.122 \\
\hline $\begin{array}{l}\text { What is the significance of the company when } \\
\text { choosing a food product? }\end{array}$ & 0.067 & 0.095 & 0.086 & 0.094 & -0.024 & 0.091 \\
\hline $\begin{array}{l}\text { What is the importance of quality for you when } \\
\text { choosing a food product? }\end{array}$ & -0.002 & 0.189 & -0.372 & $0.156 * *$ & -0.078 & 0.132 \\
\hline $\begin{array}{l}\text { What is the importance of caloric content for you } \\
\text { when choosing a food product? }\end{array}$ & -0.125 & 0.118 & 0.028 & 0.105 & 0.125 & 0.097 \\
\hline $\begin{array}{l}\text { What is the significance of composition for you } \\
\text { when choosing a food product? }\end{array}$ & 0.203 & 0.16 & -0.162 & 0.128 & 0.476 & $0.118^{* * *}$ \\
\hline Do you think you are eating healthily?_yes & 0.132 & 0.246 & -0.709 & $0.229 * * *$ & 0.739 & $0.197^{* * *}$ \\
\hline Do you use any diet (e.g. vegetable and fruit)? & 0.069 & 0.262 & 0.588 & $0.231^{* *}$ & -0.252 & 0.210 \\
\hline $\begin{array}{l}\text { Do you broaden your knowledge of proper } \\
\text { nutrition? }\end{array}$ & 0.683 & $0.261 * * *$ & -0.323 & 0.234 & 0.881 & $0.213^{* * *}$ \\
\hline $\begin{array}{l}\text { Do you use dietary supplements advertised in the } \\
\text { media? }\end{array}$ & -0.046 & 0.272 & -0.497 & $0.283^{*}$ & 0.326 & 0.219 \\
\hline sex_female & -1.033 & $0.225^{* * *}$ & -0.922 & $0.198^{* * *}$ & 0.754 & $0.185^{* * *}$ \\
\hline age_25_34 & -0.525 & $0.274 *$ & -1.265 & $0.260 * * *$ & -0.056 & 0.243 \\
\hline age_35_44 & -0.7 & $0.317^{* *}$ & -1.613 & $0.317^{* * *}$ & 0.052 & 0.271 \\
\hline age_45_54 & -1.035 & $0.337^{* * * *}$ & -2.086 & $0.340^{* * *}$ & 0.261 & 0.280 \\
\hline age_55_59 & -2.105 & $0.468^{* * * *}$ & -2.908 & $0.443^{* * *}$ & 0.024 & 0.336 \\
\hline age_60_64 & -3.102 & $0.541^{* * *}$ & -2.713 & $0.521^{* * *}$ & -0.687 & $0.322 * *$ \\
\hline age_65_and_above & -3.783 & $0.533^{* * *}$ & -4.585 & $0.599 * * *$ & -0.540 & 0.337 \\
\hline primary education & -2.933 & 2.984 & -2.492 & 1.59 & 0.299 & 0.847 \\
\hline junior high school education & -0.889 & 1.223 & -1.327 & $0.665^{* *}$ & -0.493 & 0.702 \\
\hline
\end{tabular}




\begin{tabular}{|c|c|c|c|c|c|c|}
\hline \multirow[t]{2}{*}{ Question } & \multicolumn{2}{|c|}{$\begin{array}{l}\text { Eating in restaurants } \\
\text { with international } \\
\text { cuisine }\end{array}$} & \multicolumn{2}{|c|}{$\begin{array}{l}\text { Eating in fast food } \\
\text { bars }\end{array}$} & \multicolumn{2}{|c|}{$\begin{array}{l}\text { Taking an interest in } \\
\text { new trends in nutrition }\end{array}$} \\
\hline & b & $\operatorname{std}(b)$ & b & $\operatorname{std}(b)$ & b & $\operatorname{std}(b)$ \\
\hline secondary education & 0.809 & $0.459^{*}$ & 0.086 & 0.331 & 0.045 & 0.273 \\
\hline higher education & 1.377 & $0.472^{* * *}$ & 0.06 & 0.348 & 0.035 & 0.276 \\
\hline very poor income situation & 2.845 & 1.864 & 0.871 & $0.527 *$ & 1.375 & 1.025 \\
\hline bad income situation & -1.207 & 1.192 & 0.602 & 1.106 & -1.033 & 1.422 \\
\hline good income situation & 0.368 & 0.238 & 0.387 & $0.226^{*}$ & 0.234 & 0.195 \\
\hline very good income situation & 1.362 & $0.337^{* * * *}$ & 0.93 & $0.337 * * *$ & 0.139 & 0.280 \\
\hline place of residence_city & 0.696 & 0.239 *** & 0.094 & 0.208 & 0.276 & 0.191 \\
\hline _cons & 0.252 & & 0.211 & & 0.143 & \\
\hline $\mathrm{R}^{2}$ & 637 & & 637 & & 637 & \\
\hline
\end{tabular}

Column b provides estimates of regression coefficients; column std (b) contains the average parameter estimation errors calculated using a formula resistant to random component heteroscedasticity; statistically significant estimates are marked with stars: ${ }^{*} \mathrm{p}<0.1$; ${ }^{* *} \mathrm{p}<0.05$; $* * * \mathrm{p}<0.01$

Source: own elaboration based on the results of primary research.

CHART 1

The percentage of consumers in relation to selected aspects of globalisation in their food choices

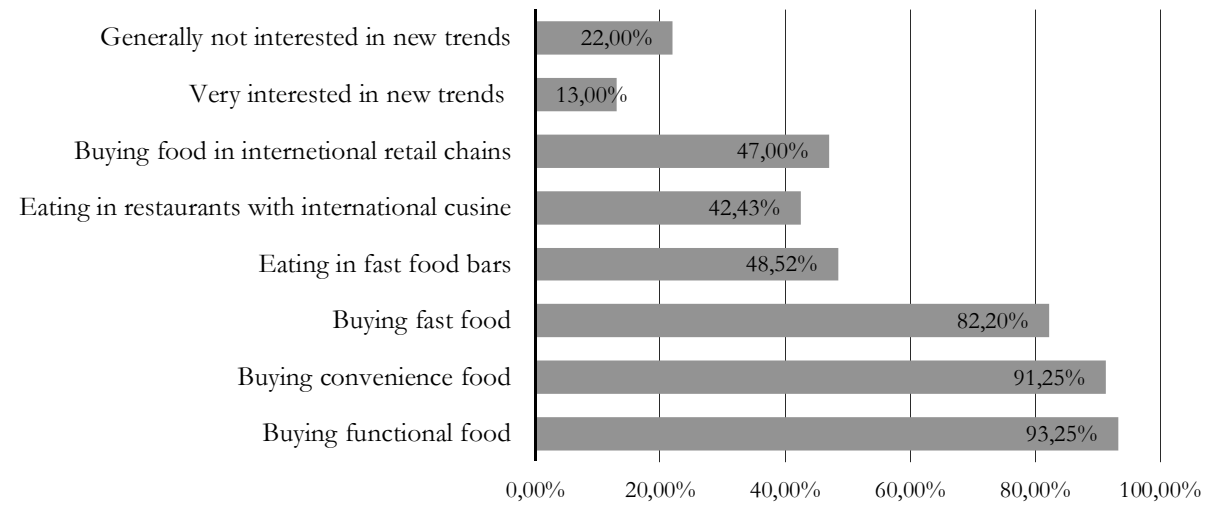

Source: own elaboration based on direct research.

In direct studies, it was shown that almost half of Poles (47\%) buy food in international retail chains, and these are less frequently people aged 35 and above than people aged 18-34. The same applies to consumers with secondary and higher education as opposed to individuals with vocational education. These results are in line with the research conducted by Wrzesińska [2006], who indicates that mostly young people have positive attitudes towards supermarkets and hypermarkets. What is more, these are people, who pay attention to the price and quality of food, as well as apply various types of diets. Interestingly, it has been shown that people who 
assess their nutrition as healthy and pay attention to packaging and the company producing the purchased food are much less likely to make purchases in international retail chains (table 5 ; chart 1 ).

It should be noted that the phenomenon of globalisation, contributing to a faster and more chaotic pace of life, also influences the development of the trend related to the purchase of fast food products, and convenience and functional food, marketed as food innovations yielding time savings. Functional food is purchased by $93.25 \%$ of Poles, convenience food by $91.25 \%$, fast food by $82.00 \%$ (chart 1 ).

Fast food, which has become an alternative or complement to consumption at home, although commonly considered unhealthy, is consumed excessively, especially by young consumers who seek comfort and time savings [Gulbicka, Kwasek, 2007, p. 7; McLean-Meyinsse et al., 2015, p. 24]. Direct research shows that fast food products are much less frequently purchased by people aged 25 and above than by persons aged 18-24. It can be noticed that with the increase in the age of consumers this difference becomes statistically more significant. The results of the research also indicate that people with higher education are more likely to buy fast food than people with vocational education. Moreover, people who assessed the income situation of their household as very good also bought this type of food more often than those who assessed the income situation of their household as average. Additionally, it can be noted that people declaring a healthy diet and paying attention to the composition of the food purchased are much less likely to buy fast food (table 5).

According to the results, convenience food is much less frequently purchased by people aged 35 and above than by people aged 18-34. Consumers with higher education significantly more often purchase this type of food than people with vocational education, whereas people with primary education do so much less often than those with vocational education. The fact that people living in the city are much more likely to buy convenience food than people living in rural areas (Table 5) is also statistically significant. The results of the direct studies are consistent with Kowalczuk [2004]. She indicates that convenience food is mainly used by young and middle-aged women, and as education and income levels increase, the tendency to use high-tech convenience food also increases. Moreover, she shows that the interest in convenience food is greater among respondents from urban areas than from rural areas, who more often declare using traditional types of concentrates in everyday cooking. It is also worth noting that the direct studies show that people preferring healthy eating, expanding their nutritional knowledge, as well as those who use different diets, are less likely to buy convenience food.

Analysing the profile of the consumer purchasing functional foods, it can be seen that people aged 55 and over are far less likely to purchase functional foods than people aged 18-24 (table 5). It should be noted that these results are similar to Jeżewska-Zychowicz et al. [2010]. They found that functional food is preferred by a higher share of younger people (44\% in the age group of $15-19,41 \%$ in the $20-29$ age group) than the elderly (22\% of people aged 60 and over). In addition, direct research shows that people assessing their income situation as very bad buy functional food more often than people who assess their household income 
situation as average. What is more, people who broaden their nutritional knowledge and pay attention to the quality and calorific value of purchased food products bought this type of food more often. No statistical significance of gender, education and place of residence of consumers on purchasing functional food has been demonstrated (table 5).

With globalisation and the rapid spread of certain patterns of behaviour in the world, it can be assumed that new trends in nutrition will have an impact on the dietary behaviour of Poles; however, only $1 / 3$ of the respondents admitted that the interest in new nutritional trends, which is associated with the introduction of fashionable products into their daily diet and the search for new ways of cooking, fits well or very well with their behaviour. As much as $1 / 5$ admitted that they are not interested in them at all. The results showed that, on average, women are more interested in new nutritional trends than men. It is also noted that people aged 60-64 on average gave lower answers to this question than people aged 18-24. It is worth mentioning that consumers preferring healthy eating, improving their knowledge in this area and paying attention to the composition of products showed, on average, more interest in new nutritional trends than others (table 5).

Subjective assessment of the diet of Poles

CHART 2

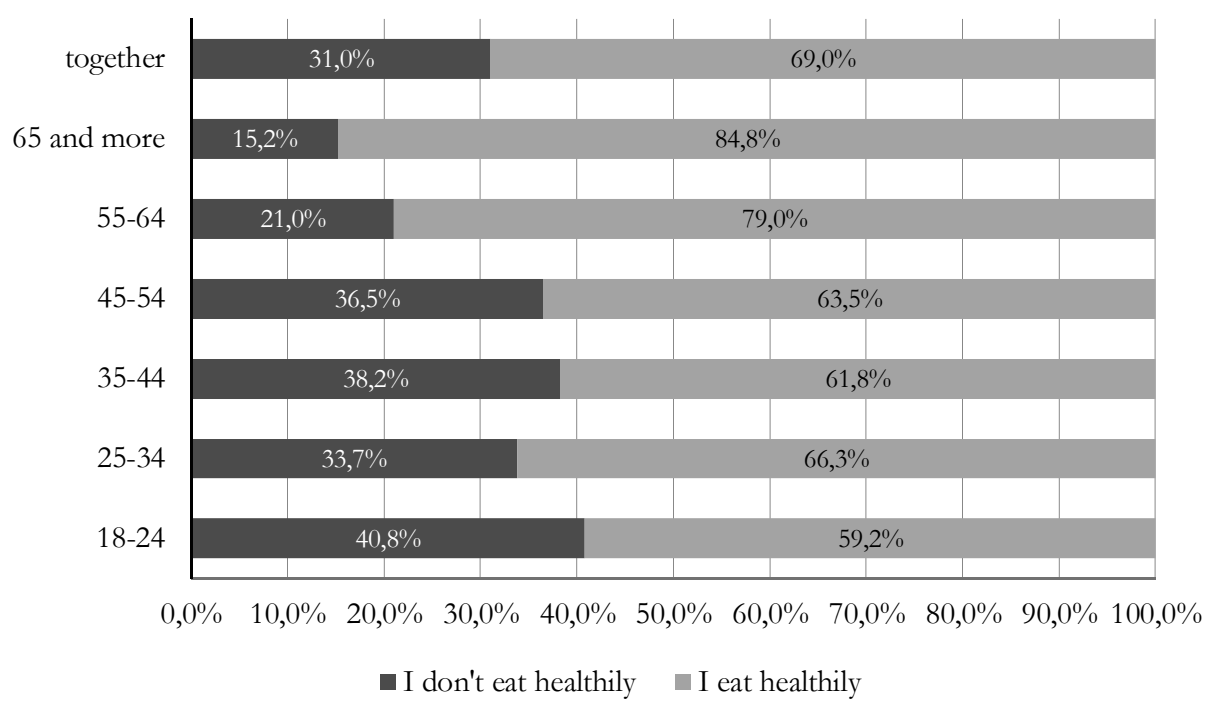

Source: own elaboration based on direct research. 


\section{Respondents' answers to the question whether they broadened their knowledge about proper nutrition in the last year}

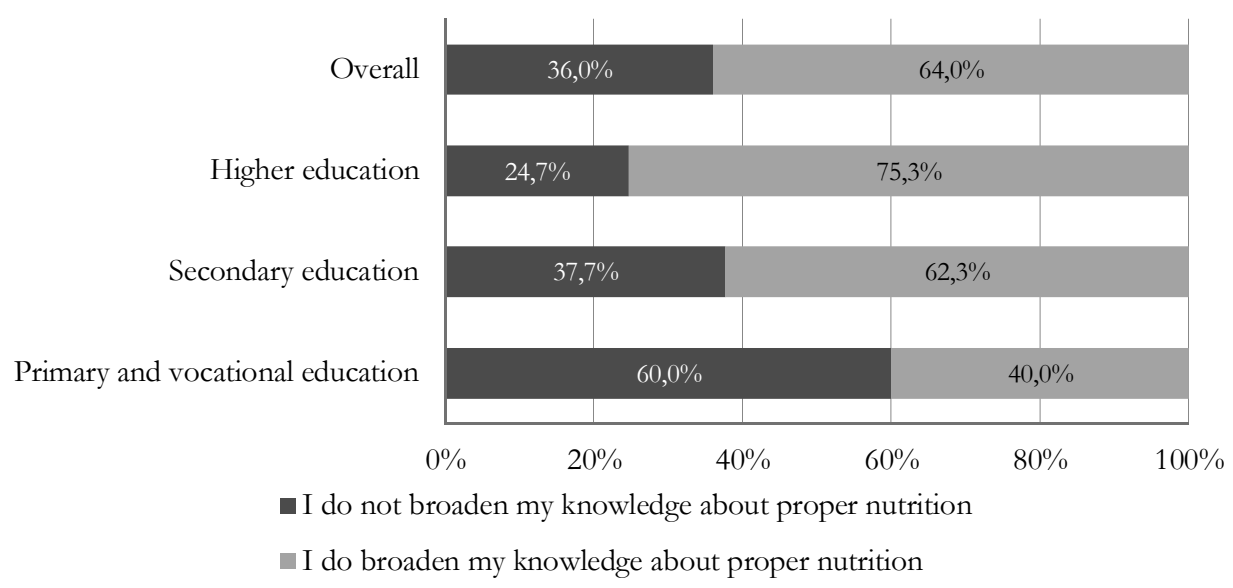

Source: own elaboration based on direct research.

Dietary choices are determined by a combination of many factors of demographic, economic and social nature. The conducted research confirmed that age, education and income were the most important of them. As can be noticed, the research showed that in relation to many aspects influencing the globalization level of Poles' food choices, the declarations concerning healthy eating and expanding the knowledge in this area were of great importance. Therefore, it is worth presenting selected results of the research related to the influence of age and education of the respondents on their diets and development of their knowledge in this area (chart 2 and chart 3).

The study found that people over the age of 64 are most likely to eat healthily, while the youngest respondents are not. People with higher education are most likely to expand their knowledge of healthy eating, and those with primary and vocational education are least likely to do so (chart 2 and chart 3 ). It should be noted that, once again, it has been shown that despite the knowledge about the harmfulness of fast food, it is the educated people who reach for it most often (table 5).

\section{Conclusions}

The main purpose of this research was to identify and characterise phenomena of globalization in the food choices of Polish consumers. Across the studies covered by this paper, it was found that globalisation is visible in the food choices of Polish consumers, and concerns primarily the younger generation (under 25), with higher education and those assessing their income situation as very good. Globalised 
consumers, who manifest these behaviours in purchasing fast food and food products from international trade chains, eat unhealthily and do not pay much attention to the composition of products. Those who are interested in new nutritional trends, however, i.e. they are open to foreign fashions, prefer healthy eating and broaden their knowledge in this field, are less likely to do so. Therefore, the hypotheses of the present study can be positively confirmed.

From a practical point of view, studies show that many consumers still prefer to buy food products from international retail chains and include in their diet convenience food, functional food and fast food, which may result from, among others, an intensive and busy lifestyle, non-standard working hours, an increase in the number of one-person households, the greater professional activity of women, an ageing population and the lack of basic cooking skills among young people. Moreover, because of the fashion for healthy, plant-based nutrition and a high level of quality factor in the selection of food products, it can be assumed that today's consumers are looking for a dietary alternative that will allow them to reduce the time it takes to prepare meals and clean up afterwards, while maintaining their health. An example is the growing demand for healthy, convenient food, which is increasingly available in most international supermarkets. It can also be assumed that there will be a growing demand for fast food bars offering healthy food from a proven source or specialising in vegetarian cuisine.

In terms of directions for future research, due to globalisation, consumers can divide their dietary choices into two groups: purchasers with quality criteria and those for whom quantity is more important. The former, due to their desire to be different, and high income and education levels, are characterised by increasing expectations in this regard. Moreover, many of the controversial changes brought about by globalisation in the world economy, including the food sector, have given rise to a large number of consumers displaying non-conformist behaviour towards the trend. Antiglobalisationists see many risks in this phenomenon, including those connected with the food sector. These are mainly related to the deterioration of food quality, the spread of civilisation diseases, resulting from the promotion of highly processed products with reduced nutritional values by transnational corporations, the dying-out of local entrepreneurship, the degradation of the natural environment, the deterioration of food security and the excessive dependence on international markets [Michalczyk, 2017, p. 36]. Hence, the phenomena of ethnocentrism and deconsumption in consumer behaviour increasingly emerge as trends alternative to globalisation and, as such, they merit further investigation.

\section{References}

Brunner T.A., van der Horst K., Siegrist M., 2010, Convenience food products. Drivers for consumption. "Appetite", vol. 55(3), pp. 498-506, DOI: 10.1016/j.appet.2010.08.017. Goetzke B., Nitzko S., Spiller A., 2014, Consumption of organic and functional food. A matter of well-being and health?, "Appetite", vol. 77, pp. 96-105. DOI: 10.1016/j. appet.2014.02.012. 
Gulbicka B., Kwasek M., 2007, Wplyw globalizacii na wysizynienie ludności w Polsce, Ekonomiczne i Spoteczne uwarunkowania rozwoju polskiej gospodarki sywnościowej po wstapieniu Polski do Unii Europejskiej, Instytut Ekonomiki Rolnictwa i Gospodarki Żywnościowej - Państwowy Instytut Badawczy, Warszawa.

Gupta N., 2011, Globalization does lead to change in consumer behavior: an empirical evidence of impact of globalization on changing materialistic values in Indian consumers and its aftereffects, "Asia Pacific Journal of Marketing and Logistics", vol. 23(3), pp. 251-269, DOI: 10.1108/13555851111143204.

Hanus G., 2018, The impact of globalization on the food behaviour of consumers - literature and research review, CBU International Conference Proceedings, vol. 6, pp. 170-174, DOI: $10.12955 /$ cbup.v6.1151.

Hughes R.G., Lawrence M., 2005, Globalisation, food and health in Pacific Island countries, "Asia Pacific Journal of Clinical Nutrition", vol. 14(4), pp. 298-305.

Jeżewska-Zychowicz M., Babicz-Zielinska E., Laskowski W., 2010, Uwarunkowania spoşycia ṡywności wžbogacanej w witaminy i sketadniki mineralne - uybrane aspekty, "Roczniki Państwowego Zakładu Higieny”, nr 61(2), s. 155-158.

Kowalczuk I., 2004, Conditions of food concentrates consumption, "Acta Scientiarum Polonorum Technologia Alimentaria”, vol. 3(1), pp. 187-198.

Lemańska-Majdzik A., Sobiegraj A., 2013, Globalization - Opportunity or Threat to Modern World, "Humanitas University's Research Papers Management", no. 1, pp. 114-125.

Maśloch P., 2013, Globalization and Market Development in Crisis, "Studies of the Industrial Geography Commission of the Polish Geographical Society", WSB Universities, Toruń, pp. 147-160.

McLean-Meyinsse P., Taylor S., Gager J., 2015, Self-Reported Consumption of Fast-Food Meals by University Students, "Journal of Food Distribution Research", vol. 46 (1), pp. 23-30, DOI:10.22004/AG.ECON.198997.

Michalczyk J., 2017, Rola procesów globalizacji i integracji europejskiej w ksztaltowanin sie tańcuchón dostaw syynności, "Ekonomia XXI wieku", nr 3(15), s. 32-53.

Michałowska M., Danielak W., 2015, The Impact of Globalization on Consumer Behavior in Lubuskie Province in the Light of the Research, "Annales Universitatis Mariae CurieSkłodowska. Sectio H Oeconomia”, vol. 3(49), pp. 135-146, DOI: 10.17951/h. 2015.49.3.135.

Niemczyk A., 2004, Konsument we wspótczesnym śmiecie, “Acta Universitatis Lodziensis. Folia Oeconomica", vol. 179, pp. 166-167.

Robbins J., 2010, Pentecostal networks and the spirit of globalization, "Contemporary Religiosities: Emergent Socialities and the Post-Nation-State", pp. 55-66.

Schultz J., 2004, Globalization, urbanization and nutrition transition in a developing island country: a case study in Fiji, "FAO Food and Nutrition Paper", vol. 83, pp. 195-214.

Ukonu I.C., 2016, The effect of fast food globalisation on students' food choice, "International Journal of Economics and Management Engineering", vol. 10(7), pp. 2331-2344. DOI:10.5281/zenodo.1125557. 
Włodarczyk K., 2015, Globalizacja a patriotyzm ekonomiczny polskich konsumentów, "Studia Ekonomiczne. Zeszyty Naukowe Uniwersytetu Ekonomicznego w Katowicach", nr 214, s. 66-67.

Wrzesińska J., 2006, Young comsuments preferences regarding to shopping in supermarkets (personal empirical research), "Scientific Journal of Warsaw University of Life Sciences, series, Economics and Organization of Agri-Food Sector", no. 59, pp. 89-100.

www 1, https://issuu.com/brogmarketing/docs/raport_gastronomiczny_2018 [date of entry: 01.08.2020]. 